\title{
KONSEP KOREOGRAFI BEDAYA HERJUNA WIWAHA
}

\author{
Dewi Kristiyanti
}

\author{
Program Studi Seni Tari \\ Fakultas Pertunjukan \\ Institut Seni Indonesia Surakarta.
}

\begin{abstract}
This research is entitled A Choreography Concept of Bedaya Harjuna Wiwaha Dance. The Yogyakarta style of Bedaya Harjuna Wiwaha dance was composed by KRT Sasmintadipuro performed in Tingalan Dalem Sri Sultan Hamengku Buwana IX in 1976. In Bedaya Harjuna Wiwaha dance, all dancers have their respective roles. The role of the dancers in Bedaya Harjuna Wiwaha dance is like the other Bedaya dance. The roles of the dancers includeEndhel Pajeg, Batak, Jangga, Dhadha, Buntil, Apit Ngajeng, Apit Wingking, Endhel Wedalan Ngajeng and Endhel Wedalan Wingking. Some of these roles represent characters in the story contained in Bedaya Harjuna Wiwaha dance, such as Prabu Newatakwaca, Harjuna and Dewi Supraba. In addition, norms or rules for the arrangement of Bedaya Harjuna Wiwaha dance include: rules for the use and application of dance motives, rules for the use and application of floor patterns, rules for the use of rhythm of motion, story sources, dance forms and dance styles.
\end{abstract}

Keywords: Choreography Concept, Bedaya Herjuna Wiwaha

\section{PENDAHULUAN}

Keraton Yogyakarta oleh masyarakat Jawa dijadikan sebagai panutan dalam hal seni dan budaya. Kerton Yogyakarta memiliki perbedaan dengan gaya keraton Surakarta dan keraton lain di seluruh nusantara. Perbedaan tersebut dapat terlihat dalam gaya tata busana, seni tari, seni musik/gamelan, seni pewayangan/pedalangan, bahasa (bahasa bagongan), seni arsitektur, tata ruang, dan seni sastra (Suryo, 2004: 14). Gaya seni budaya ini menandakan keraton Yogyakarta memiliki keistimewaan yang patut dijaga dan dikembangkan. Selanjutnya unsur budaya yang masih melekat antara lain adanya religi, adat-istiadat, etika, estetika, tingkah laku, pendidikan dan kesenian.

Tari Bedaya merupakah salah satu produk keraton yang harus terus dijaga keberlangsungannya. Tari Bedaya adalah salah satu bentuk tari kelompok yang lazimnya ditarikan oleh sembilan penari putri.
Menurut tradisinya jumlah penari dalam tari bedaya adalah 9 (sembilan) orang penari putri. Namun demikian tidak dapat kita ingkari bahwa tari Bedaya yang jumlah penarinya ada 6 (enam) orang yaitu Bedaya Sangaskara atau Bedaya Manten, dan 7 (tujuh) orang yaitu tari Bedaya Sapta, yang ditata menurut tata aturan yang baku dalam tari Bedaya. Tata aturan penyususnan tersebut merupakan suatu ketentuan normatif yang selalu dianut dan ditaati di dalam rangka penyususnan tari Bedaya gaya Yogyakarta.

Seni pertunjukan tari sebagai unsur budaya yang bersumber pada rasa, terutama rasa keindahan yang ada pada manusia. Rasa keindahan yang dapat disentuh lewat panca indera, menuntut adanya bentuk, pengaturan keseimbangan yang cermat, serta konsentrasi kecerdasan merupakan fakta sosial. Ekspresi saja tidak dapat disebut sebuah 
karya seni. Mary Wigman mengatakan bahwa, tamapa bentuk tidak dapat disebut tari (Martin, 1965: 230). Tari sebagai bentuk material yang tampak dan dapat disimak, ditangkap, dan diobservasi adalah bagian dari dunia nyata. Tetapi tari juga dapat dianggap dalam bentuk nonmaterial, yaitu merupakan fenomena yang lebih bersifat intersubjektif, yang sifatnya hanya muncul dari dalam kesadaran manusia. Dalam hal ini Herbert Read mengatakan bahwa, seni dalam kaitannya dengan fakta-fakta sosial lainnya dorongan estetis itu inheren pada manusia (1970: 3).

Perhatian utama pada penelitian ini adalah fakta sosial yang menyangkut hubungan antara individu dengan pranata sosial istana Yogyakarta. Individu dengan pengalaman hidup yang mereka terima dari dunia sekelilingnya memberi corak atau warna yang khas pada rasa seni. Perumusan masalah istana dengan pribadi Sultannya, dan pertunjukan tari Bedaya sebagai fakta sosial, menarik untuk didekati dengan teori-teori sosial budaya.

Beberapa aktivitas seni pertunjukan yang muncul dari istana Yogyakarta sejak masa pemerintahan Sri Sultan Hamengku Buwono X ini telah mengalami perubahan dan perkembangan. Dari beberapa aktivitas itu yang menarik perhatian adalah latar belakang ide, dan penciptaan tari Bedaya mengandung nilai-nilai, etika, estetika, sikap, dan pandangan hidup aristerokrat Jawa. Seperti misalnya nilai atau idiologi manunggaling kawula gusti yang meliputi cita-cita dalam sistem pemerintahan patrimonial seperti Keraton Kasultanan Yogyakarta, kita temukan norma-norma untuk meligitimasikan dan berusaha memberikan kontrol negara atas masyarakat dengan bentuk simbolis antara lain hasil seni yang mengkeramatkan raja (Kuntawijaya, 1987 :6). Pementasan kesenian sebagai bagian integral dari seluruh dinamika sosial komunitas lingkungannya, nampaknya merupakan salah satu cara efektif untuk memelihara persatuan antara Sultan dan kawulanya.

Tertarik untuk dapat memahami aspekaspek tata susunan dalam tarian tradisional Jawa, yang hidup di dalam keraton Yogyakarta yaitu tentang tari Bedaya. Dalam hal ini disadari karena betapa banyak dan kompleknya tari Bedaya, maka difokuskan pada Bedaya Harjuna Wiwaha karya
KRT. Sasmintadipuro. Sedangkan pokok permasalahannya yang dipakai sebagai pangkal pembahasan dari segi konsep koreografinya. Permasalahan itu tentu saja tidak lepas dari dasar pemikiran yang melatar belakangi terciptanya tari Bedaya tersebut.

Untuk mengetahui konsep koreografi Bedaya Herjuna Wiwaha karya KRT. Sasmintadipuro pada tahun 1976, maka harus tidak mengesampingkan kehidupan di lingkungan keraton Yogyakarta. Tari Bedaya sebagai proses simbolis merupakan kreativitas manusia yang mempunyai makna-makna tertentu dalam realitas kehidupan manusia sebagai makluk sosial. Secara eksistensial kehadiran seni pertunjukan itu tidaklah berdiri sebagai sebuah sistem yang independen, melainkan terkait menjadi keseluruhan sistem yang ada, dan berlaku dalam lingkungannya. Pemahaman terhadap tari Bedaya Herjuna Wiwaha dalam konteks sosial kesenian ini ditelusuri dalam jaringan sistem-sistem yang ada seperti sistem simbol, yaitu nilai-nilai yang ada dalam seni itu. Sistem lingkungan, yakni perkembangan seni dalam masyarakat patrimonial istana, serta norma-norma yang meligitimasikan sistem simbol itu.

Dalam tari Bedaya Harjuna Wiwaha, semua penari mempunyai peran masing-masing. Peran penari dalam tari Bedaya Harjuna Wiwaha ini seperti pada tari Bedaya yang lain. Peran-peran penari tersebut adalah Endhel Pajeg, Batak, Jangga, Dhadha, Buntil, Apit Ngajeng, Apit Wingking, Endhel Wedalan Ngajeng dan Endhel Wedalan Wingking. Dari beberapa peran tersebut mewakili tokoh dalam cerita yang terdapat dalam tari Bedaya Harjuna Wiwaha, Seperti Prabu Newatakwaca, Harjuna dan Dewi Supraba.

Tari Bedaya Harjuna Wiwaha pada dasarnya mempunyai susunan pola lantai seperti pada pola lantai tari Bedaya pada umumnya. Susunan Pola lantai tersebut adalah; rakit lajur, rakit ajeng-ajengan, rakit mlebet lajur, rakit medhal lajur, dan rakit tiga-tiga. Di dalam tari Bedaya yang satu dengan tari Bedaya yang lain memiliki perbedaan yaitu dalam formasi rakit gelar. Hal ini karena rakit gelar merupakan inti dari suatu ceritera yang dibawakan.

Memahami konteks kesenian Keraton Yogyakarta mencoba menghubungkan kesenian 
dengan kesadaran kolektif, struktur sosial, serta fungsi-fungsi kesenian dalam struktur itu, dengan tingkat kajian mengenai lingkungan sosial istana. Kajian yang sifatnya multi dimensi ini akan menyangkut pula lembaga budaya, yakni menanyakan siapa yang menghasilkan, siapa yang mengontrol, dan bagaimana kontrol itu dilakukan. Isi budaya menanyakan apa yang dihasilkan simbolsimbol, apa yang diusahakan serta efek budaya menanyakan konsekuensi apa yang diharapkan dari proses budaya atau simbol itu.

\section{PEMBAHASAN}

\section{A. Konsep Bedaya Harjuna Wiwaha}

Tari adalah bentuk pernyataan imajinatif yang tertuang dalam kesatuan simbol-simbol gerak, ruang dan waktu. Tari harus dihayati sebagai kemanunggalan dari imajinatif gerak, ruang dan waktu. Sebagai bentuk bentuk kemanunggalan maka tari merupakan bentuk pernyataan jiwa atau ekspresi, bentuk pernyataan ilusi dan sekaligus bentuk pernyataan rasional manusia, dalam gerak, ruang dan waktu yang dihadirkan sebagai satu kesatutan yang utuh. Oleh sebab itu ide atau gagasan dari penata tari merupakan wujud yang mendasari dari bentuk dan gaya tarinya Di samping itu juga sekaligus memperjelas kehadiran nilai-nilai estetis. Melihat pembicaraan itu maka secara perspektis maupun konseptual tidak mungkin dipisahkan dengan pembicaraan koreografi. estetik dan koreografi hadir dalam suatu jalinan yang tunggal dan hanya dapat dihayati melalui bentuk kesatuan symbol-simbol gerak, ruang dan waktu.

Secara historis setelah perjanjian Giyanti tahun 1755, maka kerajaan Mataram terpecah menjadi dua kerajaan, yaitu Kasunanan Surakarta dan Kasultanan Yogyakarta. Setiap kerajaan melangsungkan aktivitas sosial, religi, dan kulturalnya sendiri-sendiri, dengan berpijak pada akar budaya besar, yaitu kebudayaan Mataram. Kelangsungan social kultur, religi tersebut tercemin pada aktivitas manusianya, dalam simbol-simbol yang digunakan. Hal ini kesenian sebagai bentuk aktivitas social tidak bisa lepas dari semuanya. Seluruh aspek saling kait - mengkait secara integral bersatu dalam sebuah konsep yaitu lingkungan keraton
Melihat pernyatan di atas maka pembicaraan tentang tari Bedaya Gaya Yogyakarta, harus berawal dari pemahaman terhadap latar belakang konsep penyusunan tari Bedaya itu sendiri. Hal ini banyak bersangkut paut dengan budaya yang lain, yang meliputi kehidupan soosial, aspek religi, kepercayaan, faktor lingkungan dan lain sebagainya. Dari penelaahan latar belakang penyususnan tari Bedaya diharapkan mendapatkan dasar-dasar dan tata aturan penyususnan tari Bedaya gaya Yogyakarta, khususnya tari Bedaya Harjuna Wiwaha.

\section{Konsep Manunggaling Kawula Gusti}

Di dalam kehidupan manusia, alam pikiran manusia akan mengakui adanya suatu kenyataan. Kenyataan di dunia kehidupan ada yang bersifat nyata atau riil, yang bersifat inderawi. Kenyataan yang bersifat inderawi ini adalah keadaan dimana dapat dirasakan oleh panca indera, baik itu diraba, didengar.dicium, maupun dirasa. Namun demikian ada pula yang bersifat gaib atau maya yang tidak bersifat inderawi. Kemudian kenyataan yang sdifatnya tidak inderawi, salah satu contohnya adalah eksistensi manusia. Manusia ada dari tuhan yang bersifat gaib, maka hubungan manusia dengan Tuhan pada hakekatnya harus dihayati sebagai bentuk kenyataan inderawi dengan kenyataaan yang tertuinggi yang gaib, yaitu Tuhan yang Maha Kuasa.

Kehidupan manusia selalu berhubungan antara manusia dengan alam, manusia dengan Tuhan, dan antara manusia lahir, hidup, dan akhir dari sebuah kehidupan, merupakan hal yang pokok dan penting. Proses lahir, hidup, dan mati dalam pandangan jawa adalah sangkan parane dumadi, yang selalu melatar belakangi kehidupan manusia. Tuhan merupakan sebagi hal mutlak, Tuhan awal dari segala yang ada, Tuhan adalah hidup dari yang ada, dan Tuhan adalah akhir dari segala yang ada atau tempat mulih mulanira dumadi.

Perwujudan tertinggi dari hubungan antara manusia dengan Tuhannya tersebut dalam kebatinan Jawa disebut dengan istilah manunggaling kawula gusti, atau dalam kiasan jawa yang lain sebagai curiga manjing warangka, warangka manjing curiga. Kehidupan manusia di masyarakat seperti itu semua sebenarnya dapat dihayati di dalam 
berbagai macam bentuk aktivitas religious masyarakat jawa. Beberapa yang dapat dilakukan antara lain, melakukan bertapa (nenepi), penghormatan pada arwah leluhur, pementasan wayang kulit, penampilan kesenian keagamaan dalam rangka upacara tertentu. Suatu misal pertunjukan tari tayub, yang dipentaskan dalam upacara bersih desa, sehabis masa panen, dan sebagainya. Di lingkungan bangsawan jawa (kehidupan di keraton), sebagai salah satu bentuk aktivitas religius masyarakatnya, yang sampai pada masa kini masih dipelihara dan dilestarikan adalah pergelaran tari Bedaya. Hal ini perlu dijelaskan hubungan yang bagaimana tari Bedaya mampu dihayati sebagai suatu konsep hubungan tertinggi antara manusia dengan Tuhan, (konsep manunggaling kawula gusti).

Pada dasarnya tari Bedaya merupakan salah satu bentuk tari putri yang secara tradisional masih dilestarikan di lingkunganhidup kaum ningrat Jawa. Secara keseluruhan jumah penari tari Bedaya itu ada Sembilan. Seluruh penari dilukiskan dalam perwujudan yang sama atau kembar, yang dilambangka dengan tata rias dan tata busana yang serba sama (kembar). Walaupun dilukiskan dalam perwujudan yang sama tetapi setiap penari menduduki fungsi yang berbeda-beda. Secara lengkap nama-nama fungsional dari penari Bedaya adalah sebagai berikut; Endel pajeg, Batak, Jangga (gulu), Dada, Buntil, Apit Ngajeng, Apit Wingking, Endel Wedalan Ngajeng, Endel Wedalan Wingking.

Seluruh fungsional dari penari Bedaya, haru dimengerti di dalam hubungannya dengan pemakaian lambang-lambang atau simbul yang bersatu dengan lingkungan hidupnya. Mulai dari awal hingga akhil proses tari Bedaya dapat dianggap melambangkan manusia dalam pengertian totalitas, yakni wujud yang dimulai dari lahir (Ben Suharto, 1980: 25). Perwujudan manusia tersebut secara nyata tampak dalam suatau pola lantai tari Bedaya yang disebut dengan istilah rakit lajur, yang menggunakan formasi lima penari berderek berurutan ke belakang, sedangkan empat penari yang lain berada dalam posisi mengapit di sebelak kanan dan kirirnya. Perwujudan rakit lajur secara lengkap merupakan penggambaran wujud jasmaniah seorang manusia. Wujud manusia ini secara garis besar terbagi menjadi tiga bagian yaitu; bagian kepala dilambangakan oleh EndelPajeg, Batak dan jangga; bagian badan dilambangkan dengan Dada dan Buntil; bagian anggauta badan dilambangkan dengan sapit Ngajeng dan Apit Wingking sebagai symbol tangan kanan dan kiri, serta appit wedalan Ngajeng dan Apit Wedalan Wingking sebagai symbol kaki kanan dan kiri (Brongtodiningrat, 1971: 1).

Penjelasan tersebut menegaskan formasi pola lantai (rakit lajur) tari Bedaya merupakan symbol wujud jasmaniah manusia. Perubahanperubahan yang terjadi dalam pola lantai tari Bedaya merupakan suatu proses tari yang menyimbolkan suatu proses kehidupan manusia itu sendiri. Proses keseluruhan menggambarkan Purwa (mula/lahir), madya (hidup), danWusana (akhir) dari kehidupan khususnya manusia. Keberadaan Tuhan dalam pergelaran tari Bedaya di keraton Yogyakarta, diwakili oleh kehadiran Sultan sebagai raja dan saksi tunggal atau wakil Dewa atau Tuhan. Hal tersebut secara khusus merupakan lambing atau symbol bentuk kemanunggalan antara dewa dengan saktinya (Pujasworo, 1982 :35) Dalam hal ini, bahwa seorang raja akan menjadi kuat dan berkuasa seandainya di lingkungan hidupnya terdapat saktisaktinya., Sakti raja di samping berupa benda-benda pusaka, juga berupa orang yang sifatnya akan dapat menambah kekuatan dan kekuasaan dari seorang raja. Dalam hali ini semakin jelas bahwa para penari Bedaya merupakan salah satu wujud daripada sakti raja. Dengan demikian tari Bedaya dapat dianggap sebagai pusaka raja, yang menurut kepercayaannya akan dapat menambah kekuatan dan kekuasaannya. Hubungan antara tari Bedaya dengan Sultan sebagai saksi tunggal, pada dasarnya dapat diianggap sebagai symbol kemanunggalan antara manusia dengan dewanya (manunggaling kawula gusti).

Sebagai salah satu bentuk sakti atau pusaka raja, yang berfungsi menambah kekuatan dan kekuasaan, maka tari Bedaya dipentaskan ketika Sang Raja masih hidup, atau pada saat masa pemerintahannya masih berlangsung. Bagi seorang raja, maka saat yang sangat penting, dari seluruh masa kehadirannya sebagai raja, adalah peristiwa saat penobatannya menjadi raja. Sehingga peristiwaperistiwa semacam itu diperingati dengan upacaraupacara tertentu dalam setiap tahunnya. Oleh karena itu tari Bedaya sebagai sakti atau pusaka raja, kemungkinan besar akan dipergelarkan untuk 
memperingati peristiwa penobatan raja. Contoh yang paling dekat dan setiap tahunnya di peringati adalah penobatan raja keraton Kasunanan Surakarta dengan pementasan tari Bedaya Ketawang. Di keraton Kasultanan Yogyakarta di setiap tahunya juga menyelenggarakan pementasan tari Bedaya tetapi tari Bedaya yang dipergelarkan berbeda-beda, bahkan dalam tiga tahun terakhir adalah Bedaya baru karya Sri Sultan Hamengku Buwono X. Dari penjelasan tersebut jelas bahwa, tari Bedaya merupakan tarian tradisional istana yang dipakai sebagai sarana di dalam upacara penobatan raja.

Seluruh penjelasan di atas tersebut menunjukan tentang suatu aspek yang melatar belakangi tata penyusunan tari Bedaya. Kesemuanya menegaskan cita-cita manunggaling kawula gusti tetap menjadi tujuan hidup masyarakat Jawa khususnya masyarakat keraton. Tari Bedaya dapat sebagai contoh konsep tertinggi antara manusia hubungannya dengan Tuhannya dalam kepercayaan masyarakat Jawa. Oleh karena itu sangat jelas fungsi dan kedudukan arti pentingnya kelangsungan hidup bagi lingkungannya, khususnya bagi raja. Tari Bedaya kedudukannya sebagai pusakaakan menambah kekuatan dan kekuasaan raja. Tari Bedaya dipandang perlu untuk selalu dilestarikan dan dipakai sebagai pusaka secara turun-temurun bagi keluarga raja. Dengan demikian tari Bedaya tidak semata-mata di hayati sebagai seni pertunjukan saja, melainkan harus dihayati sebagai pemahaman terhadap seluruh ritus yang berlangsung di lingkungannya.

\section{Sumber Cerita}

Tari Bedaya adalah salah satu bentuk komposisi tari putrikelompok yang bersifat tematis. Pada umumnya tari Bedaya baik itu di Kasunanan Surakarta maupun di keraton Yogyakarta, kedudukan tema cerita sangatlah menonjol. Di dalam tari Bedaya sumber tema dapat dipetik dari ceritacerita yang bersifat mitos, legenda, ataupun cerita dalam epos Mahabarata yang diambil secara khusus mempunyaikaitan erat dengan cerita kehidupan rajaraja di Jawa. Sebagai contohcerita Panembahan Senopati, Sultan Agung, Ken Arok, dan sebagainya. Dalam hal ini sebenarnya sejauh mana kedudukan mitos dan legenda hubungannya tari Bedaya dengan kehidupan raja tersebut. Pada dasarnya mitos merupakan suatu penuturan tentang kenyataankenyataan dari suatu yang gaib yang berhubungan erat dengan makna hidup manusia dan dunianya. Mitos biasanya terkait dengan suatu kekuatan tertentu di luar diri manusia, atau adanya suatu bentuk tata kemasyarakatan dari makluk tertentu di luar kehidupan manusia, yang kenyataannya sangat berpengaruh dan turut menentukan kehidupan manusia di dunia. Dengan demikian di dalam kehidupan Jawa mitos itu dituturkan dalam cerita dewa-dewa, Kanjeng Ratu Kidul, Dewi Sri sebagai dewi kesuburan, tentang penjaga yang memelihara gunung Merapi atau Lawu, dan sebagainya. Pemikiran masyarkat Jawa Nampak cenderung pada sikap dan alam pikiran mistis. Di dalam pikiran mistis itulah kehidupan mitos dapat berlangsung dengan baik. Hal tersebut dikarenakan dasar kelangsungan hidup suatu mitos adalah kepercayaan yang tertanam dalam jiwa masyarakat. Kepercayaan atau keyakinan terhadap mitos begitu kuat, sehingga mitos oleh masyarakat dianggap mampu memberikan orientasi pada hidup dan kehidupan di dunia. Mitos juga dapat dikatakan sebagai symbol kehidupan tersendiri, yang ujudnya berupa suatu penuturan yang sifatnya sistematis dan konsisten. Dengan demikian cerita mitos yang diambil bukan saja sebagai cerita pelipur lara tetapi cerita yang berhubungan dengan akar yang paling dalam dari kehidupan orang-orang Jawa.

Legenda dianggap merupakan kenyatataan yang benar-benar pernah terjadi, yang bersifat sekuleratau keduniawian. Pada umumnya dalam sifat tertentu penuturan legenda sering berbaur dengan penuturan yang bersifat mitos. Kenyataan ini dapat dilihat pada cerita yang mengisahkan hubungan mistis antara Panembahan Senopati dengan Kanjeng Ratu Kidul, Jaka Tarub dengan bidadari Nawangwulan dan sebagainya. Di dalam Serat Babad Nitik disebutkan bahwa hubungan mistis Kanjeng Ratu Kidul dengan raja -raja Jawa dan keturunannya akan tetap berlangsung, yaitu raja yang berkuasa di Jawa (Bambang Pujasworo, 1982: 57). Dalam hal ini tentunya raja-raja yang sedang memegang pemerintahan di keraton Surakarta dan keraton Yogyakarta. Dengan demikian mitos dan legenda dalam tari Bedaya lebih dikenal cerita tentang hubungan mistis antara Panembahan Senopati dengan Kanjeng Ratu Kidul. 
Pada hakekatnya legenda selalu mengisahkan kehidupan orang-orang sakti, bendabenda yang sakti dan tempat-tempat yang keramat. Raja-raja keraton Surakarta dan Yogyakarta dapt digolongkan keturunan orang-orang sakti. Kekuatan atau kesaktian raja tidaklah selalu tampak dalam ujud phisik, akan tetapi dalam bentuk kekuatan atau penggunaan kebatinannya. Raja Mataram Islam Panembahan Senopati sebagai tauladan utama mengingat memiliki kekuatan phisik yang hebat dan kemampuan kebatinan yang luar biasa,sehingga diharapkan mampu memberikan tuah kekuasaan batin raja -raja keturunan Mataram, yang mampu mempengaruhi tingkah laku kehidupan jasmani dan rokhani masyarakat Jawa yang hidup dijaman berikutnya.

Kebanyakan tari Bedaya mengambil tema cerita mitos dan legenda, tetapi juga bidadari Bedaya yang mengambil dari cerita wayang purwa salah satunya adalah Tari Bedaya Harjuna Wiwaha. Tema cerita Bedaya Harjuna Wiwaha bersumber pada epos Mahabarata cerita Ciptaning Mintaraga. Cerita ini menggambarkan Harjuna yang sedang bertapa di gunung Ngindrakila dengan nama Begawan Suciptaning untuk meminta kepada para dewa agar para Pandawa memenangkan dalam perangan Baratayuda. Bartayuda adalah peperangan saudara antara para Kurawa dan Pandawa. Di dalam Harjuna bertapa mendapatkan berbagai godaan, naum semua rintangan dan godaan dapat dilalui yang akhirnya Harjuna mendapat hadiah pusaka bernama Pasopati dari Sang Ywang Bathara Guru. Setelah itu Harjuna diminta untuk menyingkirkan musuh para dewa yaitu raja Raksasa yang sakti mandraguna dari Negara Ngimahimantaka bernama Prabu Newatakwaca yang ingin meminang Dewi Supraba. Akhirnya Prabu Winatakwaca dapat disirnakan oleh Harjuna dengan bantuan Dewi Supraba. Suciptaning atau Harjuna kemudian dianugerahi atau diwisuda oleh Sang Ywang Bathara Guru, sebagai Ratunya para bidadari di kayangan Manik Antaya dengan sesebutan Prabu Galithi. Sedangkan Dewi Supraba diberikan sebagai istri Harjuna.

\section{Tata Aturan Penggunaan motifGerak Tari}

Kehidupan tari Jawa khususnya gaya Yogyakarta dan gaya Surakarta pada dasarnya ada tata aturan yang harus dipatuhi dan mengikat. Aturan itu berupa teknik pelaksanaan gerak maupun tata cara penyusunan sebuah jenis tari. Secara teknik aturan normatif dalam konsep tari gaya Surakarta disebut dengan istilah Hasta Sawanda. Bentuk ketentuan normatif itu terdiri dari delapan pengertian dasar yaitu; pacak, pancat, lulut, wilet, luwes, ulat, irama, dan gendhing. Delapan istilah tersebut sebenarnya mengandung pengertian yang berhubungan dengan gerak. Bentuk ketentuan normatif dengan istilah Hasta Sawanda lebih dikenal di Surakarta. Ketentuan aturan di Yogyakarta delapan ketentuan aturan itu terwadahi dalam wiraga, wirama dan wirasa, yang dijiwai dengan Joged Mataram yang terdiri dari sawiji, greged, sengguh, dan ora mingkuh (Fred Wibawa, 1981: 60-66).

Berdasarkan uraian di atas, maka dapat disimpulkan bahwa dalam melakukan suatu penyusunan tari Jawa, baik itu gaya Surakarta maupun gaya Yogyakarta harus memperhitungkan dan mentaati ketentuan-ketentuan normatif dalam penyusunannya. Kedelapan ketentuan normatif itu harus diperhitungkan bagiseorang penata tari, artinya setiap penata tari harus selalu berpijak pada norma etis lingkungan sehingga dapat menimbulkan pola kesinambungan motifgerak yang menumbuhkan sifat lulut, luwes dan irama tarinya. Hal lain yang tidak kalah pentingnya adalah perhitungan tentang ketentuan-ketentuan normatif dalam penyusunan pola lantai atau komposisi lantainya.Sluruhnya harus disadari dan harus dilakukan akan dasar-dasar filosofisnya dan makna-makna akan lambing kehidupannya. Dengan demikian dalam penyusunan Atari Bedaya Srimpi harus berpijak pada ketentuanketentuan normatif, sehingga penting untuk diketahui bagaimana caranya untuk mewujudkan ketentuan normative itu sekaligus memperhitungkan dengan sifat lulu, luwes, irama, dan norma etis lingkungannya.

\section{Tata Aturan penggunaan Pola Lantai}

Tata aturan yang berupa ketentuanketentuan normative dalam penggunaan dan penerapan pola lantai pada susunan tariBedaya gaya 
Yogyakarta, dapat dipahami dan dihayati dari kebiasaan yang masih berlaku dalam penyusunan pola lantai Tari Bedaya yang paling tua di keraton Yogyakarta. Tata aturan pola lantai tari Bedaya gaya Yogyakarta berdasar pada ketentuan-ketentuan tertentu. Ketentuan tersebut merupakan ketentuan normative yang terbagi dalam, ketentuan normative tata susunan penari dalam setiap formasi atau pola lantai dan ketentuan normative dalam menerapkan proses dan tata aturan pola lantainya.

Di bawah ini ketentuan normativ dalam proses dan tata urutan pola lantai, sekaligus tata letak dan tata susunan penarinya dalam setiap formasi pola lantai

\section{Rakai Lajur.}

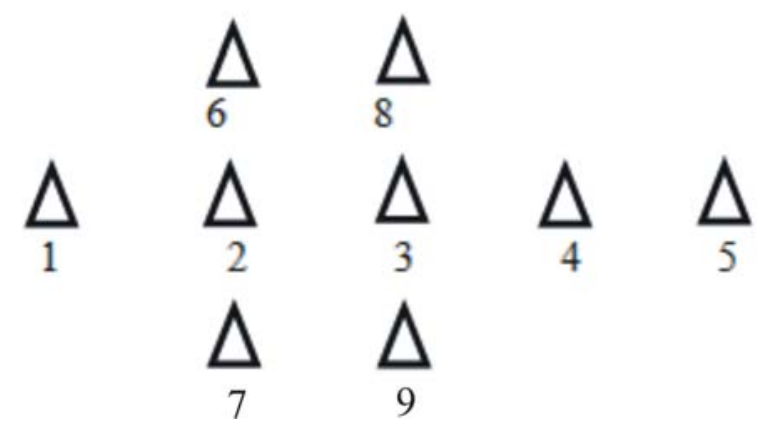

Formasi tersebut mempunyai tata urutan sebagai berikut; 1.Endel Pajeg, 2. Batak, 3. Jangga (Gulu), 4. Dhadha, 5, Buntil, 6, Apit Ngajeng, 7, Apit Wingking, 8. Endel Wedalan Ngajeng,

9.Endel Wedalan Wingking

\section{Iring-Iringan}

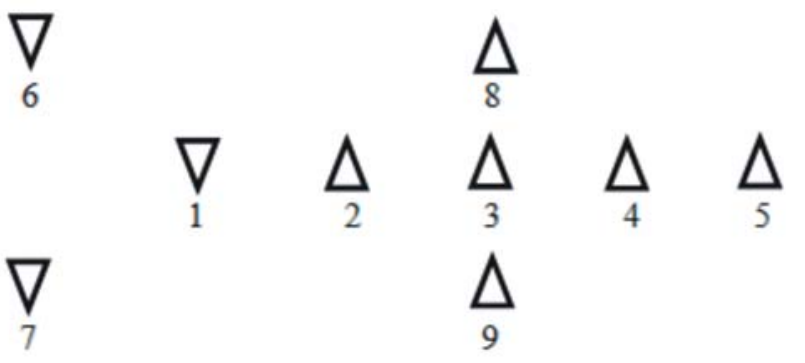

Dari rakit lajur menuju formasi iring-iringan didahului deng suatu proses Endhel, Apit nyamberiring iringan.

\section{Ajeng-ajengan}

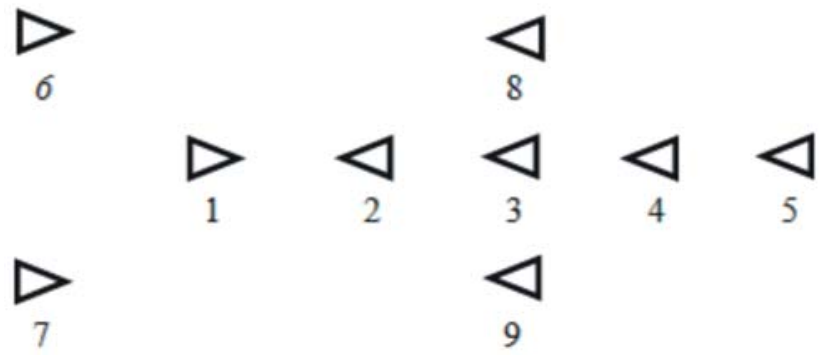

Ajeng-ajengan merupakan posisi berhadapan antara Endhel-Apit dengan lajur yaitu Batak, Jangga, Dhadha, Buntil dan Endhel wedalan Ngajeng serta Endhel Wedalan Wingking. Dari iring-iringan menuju ajengajengan dilakukan dengan suatu proses sendi gerak memutar arah hadap badan ke kiri seperempat lingkaran (Bambang Pujasworo, 1982: 77).

\section{Iring-iringan Endhel Apit Jengkeng}<smiles>[C+]1C=C1</smiles>

$\bigvee_{7}$ $\triangle_{8}$

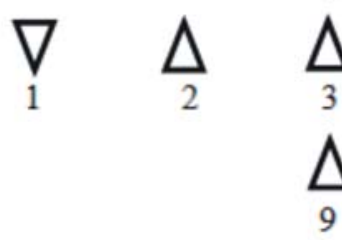

Pada formasi ini Endhel Pajeg, Apit Ngajeng, Apit Wingking berada pada posisi rendah (jengkeng) sedangkan lajur (Batak, Jangga, Dhadha, Buntil), dan Rndhel Wedalan Ngajeng, Endhel Wedalan Wingking berada dalam posisi tinggi (berdiri). Endhel-Apit serta lajur bersama Endhel Wedalan berada dalam posisi beriringan dan pada arah hadap berlawanan.

\section{Ajeng-ajengan}

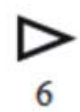

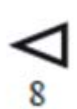

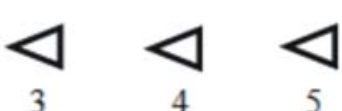


jengkeng iring-iringan. Dalam posisi ini ajengajengan atau berhadapan antara Endhel Apit dengan lajur dan Endhel Wedalan, merupakan tanda yang mengawali tata laku Endhel-Apit mantuk lajur (kembali masuk lajur).

\section{Proses Endhel Apit kembali lajur}

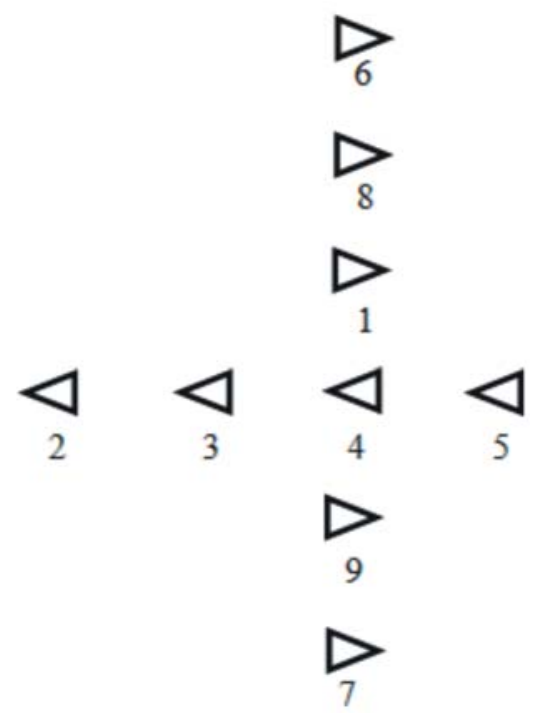

Terwujudnya formasi ini dilakukan dengan memakai motif gerak yang bersifat milir atau gerak yang berpindah. Untuk Endhel Pajes - Apit dan Endhel Wedalan Ngajeng, Edhle Wedalan Wingking, dengan diselingi gerak ngancap sebagai transisi untuk masuk lajur. Sedangkan untuk Batak, Dhadha, Jangga, Buntil, dipakai motif gerak tari yang bersifat mandeg (berhenti). Proses tersebut dicapai setelah Endhel Pajeg, Apit Wingking,Apit Ngajeng dan Endhel Wedalan Ngajeng,Endhel Wedalan Wingking melakukan gerak ngancap sebagai transisi, sehingga penari membentuk formasi masuk lajur(Bambang Pujasworo, 1982: 79).

\section{Formasi masuk lajur}

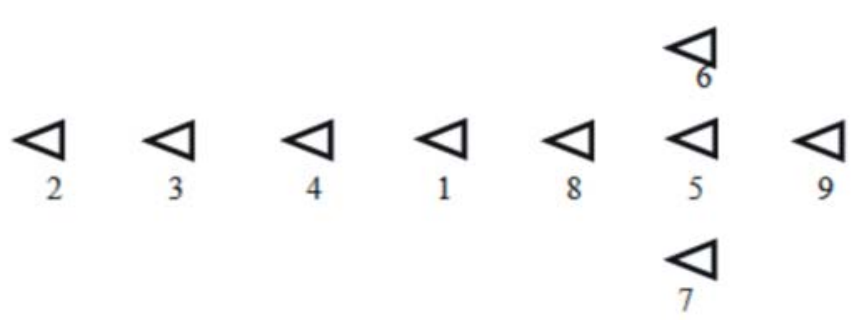

\section{Endhel - Apit keluar dari lajur}

Keluar dari lajur merupakan proses untuk menuju pada formasi rakir lajur. Dalam keluar lajur maka arah gerak Endhel Pajeg, Endhel Wedalan Ngajeng, Apit Ngajeng mengarah ke samping depan, sedangkan Endhel wedalan Wingking, Apit wingking arah geraknya kesamping belakang. Motif gerak yang dipergunakan adalah motif gerak milir atau berjalan kemudian diakhiri dengan transisi ngancap. Hal ini Batak, Jangga, Dhadha, dan Buntil, mempergunakan motif gerak mandeg atau berhenti, kemudian diakhiri dengan transisi ngancap (Bambang Pujasworo, 1982:80).

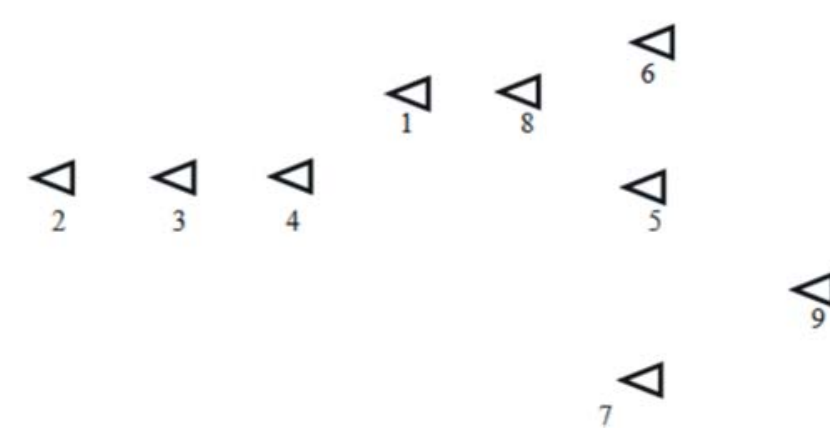

9. Rakai Lajur.

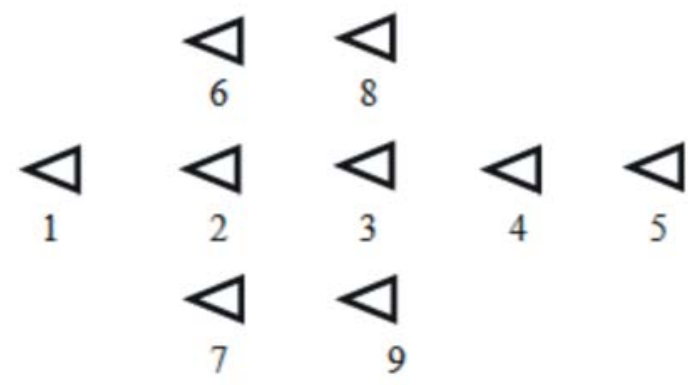

Dilanjutkan dengan formasi

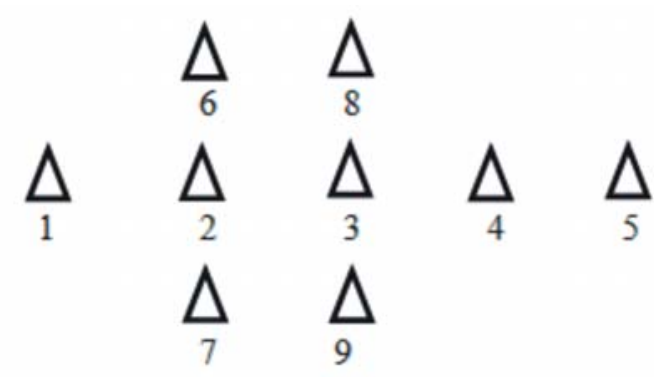

Seluruh pola lantai yang dilakukan di atas, secara berturut-turut merupakan rangkaian yang bakudal pola susunan tari Bedaya gaya Yogyakarta. 
Ketentuan normative dilakukan dalam rangkaian yang diterapkan pada bagisn gendhing dan ladrangan dengan berakirnya dengan formasi rakit tiga-tiga. Pengulangan pola lantai pada dasarnya dapat dilakukan setelah bentuk rakit lajur yang pertama hingga pada bentuk rakit lajur berikutnya dilakukan. Pengulangan formasi dilakukan dengan proses Apit nyolongi kemudian dilanjutkan dengan formasi ajeng-ajengan dan selanjutnya. Biasanya pengulangan ini dapat berlangsung satu kali atau dua kali dengan berakhir pada formasi Endhel Pajeg, Apit jengkeng iring-iringan. Untuk selanjutnya seluruh proses formasi tersebut ditutup dengn formasi rakit tiga-tiga. Dengan demikian penggambaran pola lantai dan formasi terangkai secara berurutan dengan jelas menunjukan adanya siklus. Siklus tersebut menggambarkan tentang suatu kesadaan yang bermula adari awal,harus kembali pada awal mulanya (Bamabang Pujasworo, 1982: 81).

Seluruh proses yang terurai tersebut setelah selesai dilakukan kemudian dilanjutkan pada bagian akhir tari Bedaya yang disebut dengan rakit gelar. Pada bagian ini sering desbut dengan istilah bagian ketawangan. Hal ini di karenakan bagian rakir gelar ini di iringi dengan gendhing yang berjenis ketawang. Pola lantainya diawali dari formasi tigatiga. Biasanya diawali dengan bawa swara yang dilakukan oleh swarawati di lanjutkan dengan gendhing ketawang. Pola geraknya diawali dengan motif gerak sembahan kemudian dilanjutkan motif gerak bangomate. Untuk selanjutnya diikuti dengan motif gerak yang lain. Formasi pola lantainya bebas menurut kehendak atau kemauan penata tarinya.

\section{Rakit tiga tiga}

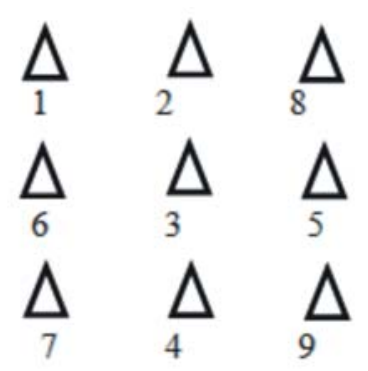

Di dalam rakit gelar diawali dari rakit tigatiga kemudian menuju rakit lajur. Dari rakit tigatiga untuk menuju rakit lajur ini pada umumnya dipergunakan transisi gerak nyamber. Untuk selanjutnya dari rakit laju menuju rakit ajengajengan biasanya didahului dengan proses Apit nyolongi, kemudian menuju iring-iringan, dilanjutkan dengan rakit gelar kemudian kembali ke rakit tiga-tiga lagi. Dengan demikian semua rangkaian tari Bedaya telah selesai, kemudian para penari melakukan lampah pocong untuk menuju pada suatu formasi rakit lajur, kemudian berjalan kapang-kapang untuk meninggalkan tempat pentas. Demikian seluruh proses yang diterapkan dalam susunan pola lantai tari Bedaya gaya Yogyakarta. Semua itu pada dasarnya ditata bukan untuk mencapai dramatik dan dinamika tertentu, tetapi ditata berdasar faham filosofi atau keyakinan masyarakat Jawa untuk menyimbolkan sebagai suatu siklus. Oleh sebab itu maka pola lantai dan formasi para penari Bedaya sebagai penggambaran siklus pikiran manusia, yang diawali dari keadaan yang tetap kemudian goyah, dilanjutkan dengan pencapaian kesadaran dan akhiri dengan kemanunggalan (Bambang Pujasworo, 1982: 84).

\section{SIMPULAN}

Tari Bedaya merupakan peninggalan budaya dari masa lampau yang sangat menarik. Tari Bedaya sampai sekarang masih terpelihara sangar baik di lingkungan keraton Yogyakarta, bahkan tari Bedaya merupakan sebuah legitimasi bagi seorang Sultan yang bertahta. Oleh karena itu tari Bedaya selalu dipergelarkan dalam setiap punya hajad baik itu dalam rangka peringkatan pengangkatan Sultan, peringatan Hadeging Negari maupun dalam acaraacara penting dalam keraton. Menurut tradisi di keraton Yogyakarta setiap Sultan yang bertahta selalu membuat tari Bedaya. Sultan Hamengku Buwana X misalnya telah memiliki karya tari Bedaya, Sang Amurwabumi, Harjuna Wijaya, dan yang terakhir adalah Bedaya Tirta Hayuningrat.

Kehidupan di lingkungan keraton tidak akan lepas dari social kultur lingkungannya, segi etis dan 
etika maupun religi. Dalam hal ini tariBedaya tercipta dari simbol-simbol kehidupan dan keyakinan masyarakat di lingkungan keraton. Seluruh tata laku tari Bedaya, formasi pola lantai gerak tari, iringan tari,dan sebagainya semuanya menunjukkan adanya pemikiran yang begitu dalam. Hal itu tidak hanya terbatas pada masalah bentu dan gaya tarinya saja, tetapi secara lebih jauh juga menyangkut tentang masalah yang hubungannya dengan aspek budaya lain. Tari Bedaya termasuk Tari Bedaya Harjuna Wiwaha sangat tidak lepas dari masalah aspek sosial, aspek religi, filsafat, norma, etika dan estetika, serta pemerintahan yang bersangkut paut dengan kekuasan raja, dan sebagainya. Dalam hal tersebut tari Bedaya dapat dihayati sebagai sakti raja, yang menambah kekuatan raja, kekuasaan dan kesuburan serta kesejahteraan rakyat dan negara. Oleh sebab itu para Sultan yang bertahta di keraton Yogyakarta selalu menciptakan tari Bedaya.

Bentuk dan gaya tari Bedaya Harjuna Wiwaha tersusun dari suatu kesatuan bentuk tari Bedaya Harjuna Wiwaha terangkai dari suatu kesatuan motif gerak tertentu, yang berbeda dengan kesatuan motif gerak dalam bentuk tari yang lain. Seluruh motif gerak yang dipakai dalam tari Bedaya Harjuna Wiwaha tersusun dari kesatuan gerak yang dilakukan secara cermat atau wijang dalam tempo dan irama gerak yang ajeg. Sedangkan gaya tari Bedaya Harjuna Wiwaha sebagai satu kesatuan yang selaras dengan bentuk tarinya. Keselarasan itu dapat dilihat dari hubungan bentuk tari Bedaya Harjuna Wiwaha dengan pola lantai, irngan tarinya, irama gerak tarinya, dan tata rias serta busananya. Semua itu merupakan salah satu aspek dalam totalitas kehadiran nilai-nilai estetis tari Bedaya. Yang etrpenting itu bagaimana mewujudkan bentuk dan gaya tarinya menjadi suatu kesatuan yang utuh, selaras dan seimbang. Oleh sebab itu untuk memahami konsepsi suatu tari harus dilihat secara total, tidak dapat dilihat sepotong-potong. Demikianlah konsep koreografi Bedaya Harjuna Wiwaha dapat dipahami secara jelas dan rinci baik dari segi motif gerak, hubungan motif gerak dengan sendi gerak, motif gerka yang satu dengan motif gerak berikutnya, motif gerak dengan pola lantai, irama gerak dan ritme gerak, iringan tari, serta tata rias dan busana tarinya.

\section{KEPUSTAKAAN}

Adshead, Janet. 1988. Dance Analysis Theory and Practice. London: Cecil Court.

Beck, William M.D. 1996. The Encyclopedia

Americana International Edition .

Danbury Connecticui :Grolier in

Corporated.

Suharto, Ben. 1987. "Pengamatan Gambyong

Melalui Pendekatan Berlapis Ganda".

Kertas Kerja disajikan dalam Temu Wicara

Etnomusikologi III di Medan tanggal 2

sampai dengan 5 Februari 1987.

Dewan Ahli Yayasan Siswa Among Beksa. 1981.

Kawruh Joged Mataram. Yogyakarta

Djelantik, A.A.M. 1999. Estetika Sebuah

Pengantar. Bandung: Masyarakat Seni

Pertunjukan Indonesia.

Edi Sedyawati, ed. 1986. Pengetahuan Elementer

Tari dan Beberapa Masalah Tari. Jakarta:

Direktorat Kesenian Proyek Pengembangan

Kesenian Jakarta, Departemen Pendidikan dan Kebudayaan.

Ensiklopedi Wayang Purwa (compendium).

1977. Jakarta: Departemen Pendidikan dan

Kebudayaan.

Fred Wibawa. 2002. Tari Klasik Gaya

Yogyakarta. Yogyakarta: Yayasan Bentang

Budaya.

Gray, Hendry F.R.S. 1901. The Classic Collec

tion Edition. New York: Bountey Books 
Hawkins, Alma M. 1965. Creating Through Dance. Englewood Cliffs: Prentice-Hall, Heddy Shri Ahimsaputra. 2000. "Wacana Seni dalamAntropologiBudaya: Tekstual, Kontekstual dan Post modernistis", dalam Heddy Shri Ahimsa Putra (ed); Ketika Or ang Jawa Nyeni. Yogyakarta: Galang Press.

Herusatoto, Budional. 1985. Simbolisme dan

Budaya Jawa. Yogyakarta: Heninda.

Kuswaji. 1981. "Busana Tari Klasik Gaya

Yogyakarta" dalam Mengenal Tari Klasik

Gaya Yogyakarta. Yogyakarta: Bidang

Kesenian Propinsi DIY.

Pujasworo, Bambang. 1982. "Studi Analisis Estetika Koreografis Tari Bedaya Lambang Sari." Yogyakarta: ASTI Yogyakarta. . 1984. "Pengaruh Sistem Nilai Budaya Kaum Ningrat Jawa Terhadap Kehidupan Seni Keraton Yogyakarta.” Yogyakarta: ASTI Yogyakarta.

Suharto, Ben. 1997. "Paes Ageng Beksa Bedaya" Sebuah Kajian Estetika dalam Makna yang Berlapis Ganda. Yogyakarta: Laporan Penelitian ISI Yogyakarta. Sumandiya Hadi, Y 2001. "Pasang Surut Tari Klasik Gaya Yogyakarta Pembentukan Perkembangan dan Mobilitas." Yogyakarta: Laporan Penelitian ISI Yogyakarta.
Suryobrongto, GBPH. 1981. "Penjiwaan Tari Gaya Yogyakarta" dalam Mengenal Tari Klasik Gaya Yogyakarta. Yogyakarta: Bidang Kesenian Propinsi DIY.

Wibawa, Fred (ed). 1982. Mengenal Tari Klasik Gaya Yogyakarta. Yogyakarta: Dewan Kesenian Propinsi DIY. 